DOI: 10.20472/IAC.2017.032.010

ASLI DALDAL

Yildiz Technical University, IIBF, Dept of Politics, Turkey

\title{
THE OLD AND NEW FORMS OF POLITICAL FILMMAKING IN TURKEY
}

\begin{abstract}
:
There are many ways of analysing films from a "political" perspective. One common approach is to look at the "content" of the film and classify it as "political" if the film talks about a certain political event. This is an insufficent way of looking at films, as "politics" can involve not only the "content" of the film, but its very "form", philosophical depth, socio-political background, production conditions, audience relationship, marketing and so on. That's why "independent" cinema today is almost synonymous with "progressive" or "political" cinema even though the film may not center around an obvious political event. This paper aims at examining the "political cinema" of Turkey starting after the 1960 Coup d'Etat. The short lived "Social Realist" Movement had an overt political overtone as well as Yılmaz Güney, who after 1970, made films focusing on the agonies of the working class. Reminiscent of Italian neo-realism with their minimalist styles, mostly non professional or lesser known actors and on location shooting, these films were clearer examples of a "political" cinema in Turkey. After 1990s though, a novel look at "socially engaged" cinema started to emerge as independent films replaced the old "Yeşilçam" productions. Yeşim Ustaoğlu, Derviş Zaim, Nuri Bilge Ceylan and Zeki Demirkubuz were among the most prominent filmmakers who had an "indirect" relationship with politics. Nuri Bilge Ceylan, for example, hardly had anything overtly political in his films although his extreme emphasis on avoiding any contact with the "film market" clearly indicated a subtle political choice. After the first "wave" of independen cinema in Turkey which culminated with the international success of Distant at Cannes in 2003, a second wave emerged with younger filmmakers (including many female directors) who focused on the "micro" political discourses of those marginalised from the "decent" life of the "neo-bourgeois". Among them, Hüseyin Karabey, Orhan Eskiköy, Özgür Doğan, Pelin Esmer, Belmin Söylemez reflected those who had an "accented" (in Hamid Naficy's terms) lifestyles that, in a postmodern guise, pronounced a new political discourse mostly based on "identity" problems.
\end{abstract}

\section{Keywords:}

Independent Cinema, Turkish Cinema, Political Cinema

JEL Classification: Y90 